\title{
Serum Lactate, AST, ALT in Male Autistic Children in Bangladesh
}

\author{
Mahmuda Karim ${ }^{1}$, Shelina Begum ${ }^{2}$, Shorifa Shahjadi
}

\begin{abstract}
Background: Mitochondrial dysfunction has been found associated with abnormal brain bioenergetics resulting in autistic spectrum disorder (ASD).Objective: To assess serum lactate, AST, ALT in order to observe the mitochondrial dysfunction in male children with autistic spectrum disorder. Method: This case-control study was conducted in the Department of Physiology of Bangabandhu Sheikh Mujib Medical University (BSMMU), Shahbag, Dhaka from January, 2013 to December, 2013. Total 100 male children with age range 3-8 years were randomly selected, among which 50 were normal children and 50 were diagnosed autistic children. Autistic children were enrolled from the Parent's Forum for autistic children in Dhaka and the control subjects were selected from normal school. Serum lactate, Aspartate Aminotransferase (AST) and Alanine Aminotransferase (ALT) were estimated in all children by standard laboratory method. Independent sample ' $t$ ' test was used for statistical analysis. Results: All these biochemical parameter were found significantly higher $(\mathrm{p}<0.001)$ in ASD children. In addition, elevated levels of serum lactate, AST and ALT were found in $94 \%, 46 \%$, and $30 \%$ of autistic children respectively. Conclusion: From the result of this study it can be concluded that mitochondrial dysfunction may occur in children with autistic spectrum disorder.
\end{abstract}

Key words: Autistic spectrum disorder, Mitochondrial dysfunction, Lactate, Aspartate aminotransferase, Alanine aminotransferase.

J Bangladesh Soc Physiol. 2015, December; 10(2): 56-60

For Authors Affiliation, see end of text.

http://www.banglajol.info/index.php/JBSP

\section{Introduction}

A

utistic spectrum disorders (ASDs) is a

1 associated with altered behavior of communication of a person. ${ }^{1}$. The word spectrum refers to a wide range of disorders having different domains according to severity of features ${ }^{2}$. It is a generalized term for a group of complex brain disorder having feature of impaired social interaction, verbal and nonverbal communication, repetitive and restricted behavior $^{3}$. It usually appears within first three years of life ${ }^{1}$ and males are more affected ${ }^{3}$.

Received June 2015; $\quad$ Accepted August 2015
Abnormal brain bioenergetics and dysfunction of mitochondria can cause autism ${ }^{4}$. Autistic spectrum disorders manifest disruption in multiple high energy organ system like central nervous system, muscular and gastrointestinal systems. So, mitochondrial dysfunction is important factor which lead to cellular function impairment. This may lead to cognitive impairment, language deficits and abnormal energy metabolism in autistic spectrum disorders ${ }^{5}$. A recent study revealed that $80 \%$ children with autistic spectrum disorder may have mitochondrial dysfunction ${ }^{6}$. 
Cerebral folate deficiency, vitamin $\mathrm{B}_{6}$ or iron deficiency, genetic mutation, certain environmental toxin such as pesticides or heavy metals chemicals can impair mitochondrial activity ${ }^{7,8}$. In mitochondrial dysfunction excess reactive oxygen species (ROS) are produced which deplete GSH store in cell. As a result cells are more vulnerable to oxidative stress and damage from mitochondrial ROS. ${ }^{9}$

The mitochondrial disorders are characterized by various clinical, biochemical, molecular and histological features. Biochemical parameters for mitochondrial dysfunction include increased serum lactate, aspartate aminotransferase (AST) and alanine aminotransferase (ALT) ${ }^{6}$

Autistic spectrum disorder children with mitochondrial dysfunction show impaired TCA cycle due to some enzyme deficiency, abnormal nutrients metabolism or nutritional deficiency. Impaired TCA cycle stops aerobic respiration which initiates anaerobic respiration causing increased level of lactate. ${ }^{10}$

Mitochondrial dysfunction causes loss of some cellular integrity of certain organ such as muscle and liver and enzymes of these organs come out of cell. So aspartate aminotransferase and alanine aminotransferase are released and serum level of these enzymes rises ${ }^{1}$.

In USA, serum lactate, AST and ALT found increased in $76 \%, 36 \%$ and $52 \%$ of autistic spectrum disorders children. ${ }^{11}$ In 2006, a study on mitochondrial dysfunction with autism, reported elevation of serum AST in 38\% autistic children ${ }^{12}$.Therefore, estimation of serum lactate, ALT, AST can be useful in evaluation of mitochondrial dysfunction in autistic spectrum disorder. ${ }^{13}$ This study aimed to observed levels of ALT, AST and lactate to evaluate mitochondrial dysfunction in autistic spectrum disorder (ASD).

\section{Methods}

This case control study was conducted in the Department of Physiology of Bangabandhu
Sheikh Mujib Medical University (BSMMU), Shahbag, Dhaka from January, to December, 2013. Total 100 male children with age range 3 8 years participated in this study. Fifty autistic children diagnosed by psychiatrist according to Childhood Autism Rating Scale (CARS) ${ }^{14}$ taken from the Parent's Forum, Directorate Generals of Health Service( DOHS), Mohakhali, Dhaka and fifty control children was selected from some normal school. After selection of the subject, thorough information was given to their parents about the objective and study procedure. Their parents were encouraged for voluntary participation with their children. When their parents agreed for participation then an informed written consent was obtained from their parents. The protocol of this study was approved by the Institutional Review Board of BSMMU. Children with epilepsy, turner syndrome, down syndrome and any kind of medication were excluded from this study. The parents of all subjects were requested to attend the Department of Physiology of BSMMU, Dhaka at 9:00 AM for examination of their children. Detail personal, medical, family, socioeconomic and dietary histories of the children were recorded in a data schedule. Thorough physical examinations of the subjects were done. Anthropometric measurement including height and weight were taken and BMI was calculated. Then under aseptic precaution, $5 \mathrm{ml}$ of venous blood were collected from antecubital vein from each subject of both groups for biochemical test. Serum lactate level was measured in the laboratory of the Department of Biochemistry, BIRDEM General Hospital by colorimetric method. Serum aspartate aminotransferase (AST) and alanine aminotransferase (ALT) level were measured in the laboratory of the Department of Biochemistry, BSMMU by auto analyzer using kit from IFCC (International Federal Clinical Chemistry). Data were expressed as mean $\pm \mathrm{SE}$ and also in percentage. Statistical analysis was done by using SPSS for windows version 16. Independent samples ' $t$ ' test were used as the tests of significance.. $P$ value $<0.05$ was accepted as significant. 


\section{Results}

All the subjects of this study were similar for age and BMI. (Figure 1).

In this study mean values of serum lactate, AST and ALT levels were significantly higher $(\mathrm{p}<0.001)$ in autistic children in comparison to that of normal children (Table I).Abnormally higher level ${ }^{15-16}$ of serum lactate, AST, ALT were found in $94 \%, 46 \%$ and $30 \%$ respectively in autistic children. No control children had elevated levels of these parameters (Table II).

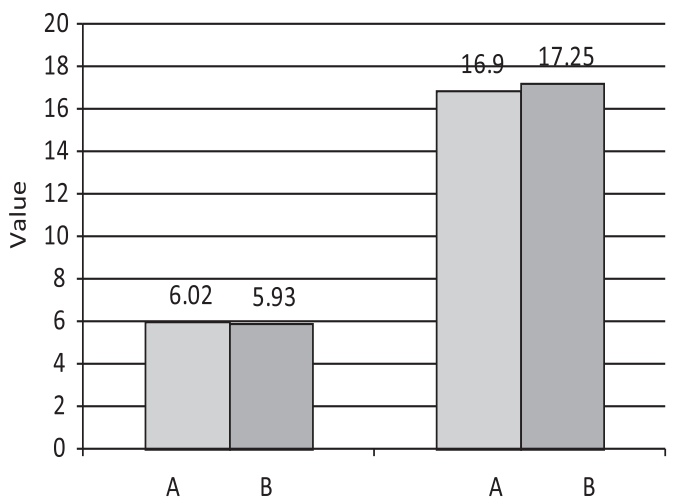

Figure 1: Mean Age (years) and Body mass index $(\mathrm{BMI})\left(\mathrm{kg} / \mathrm{m}^{2}\right)$ of study subjects. $\mathrm{A}=$ Control and $\mathrm{B}=$ Autistic children

Table I: Serum lactate, AST and ALT of both groups $(n=100)$

\begin{tabular}{lcc}
\hline Variables & $\begin{array}{c}\text { Control } \\
(\mathrm{n}=50)\end{array}$ & $\begin{array}{c}\text { Autistic } \\
(\mathrm{n}=50)\end{array}$ \\
\hline Serum Lactate & $12.10 \pm 0.34$ & $29.31 \pm 1.32 * * *$ \\
$(\mathrm{mg} / \mathrm{dl})$ & $(8-17)$ & $(16-56)$
\end{tabular}

Serum AST(U/L) $24.20+0.8236 .24+1.73 * * *$

$$
(15-35)
$$

Serum ALT (U/L) 37.14+ 1.48 49.06+2.47***

$$
(17-56) \quad(28-81)
$$

Data are expressed as Mean \pm SE. Independent sample ' $t$ ' test was used for statistical analysis. Figures in parentheses indicate ranges. $* * * p<0.000$
Table II: Frequency by elevated levels of serum lactate, AST and ALT of study subjects.

\begin{tabular}{lccccc}
\hline Variables & \multicolumn{2}{c}{ Control $(\mathrm{n}=50)$} & & Autistic $(\mathrm{n}=50)$ \\
\cline { 2 - 3 } \cline { 5 - 6 } & No & $(\%)$ & & No & $(\%)$ \\
\hline Serum lactate & 0 & $(0)$ & & 47 & $(94)$ \\
Serum AST & 0 & $(0)$ & & 23 & $(46)$ \\
Serum ALT & 0 & $(0)$ & & 15 & $(30)$ \\
\hline
\end{tabular}

Cut point ${ }^{(15-16)}$ for serum lactate $>15 \mathrm{mg}, \mathrm{AST}>35 \mathrm{U} /$ $\mathrm{L}, \mathrm{ALT}>56 \mathrm{U} / \mathrm{L}$

\section{Discussion}

The present study was undertaken to observe some biochemical variables in male children with autistic spectrum disorders in order to evaluate their mitochondrial dysfunction. Mitochondrial dysfunction were assessed by estimating serum lactate, aspartate aminotransferase (AST) and alanine aminotransferase (ALT) level in male children with autistic spectrum disorders. All these variables were also studied in apparently healthy age and BMI matched male children for comparison. In this study, mean values of all the biochemical variables of control children were within physiological limit and were almost similar to those reported by different investigators $^{2,12,17-19}$.

In this study, significantly higher level of serum lactate, AST and ALT in the autistic children was agreed to other investigators. ${ }^{2,12,13,19-23}$ Though higher lactate level were observed by some investigators ${ }^{2,6,24}$ but it was not significant.

Again, elevated serum lactate in 94\%, AST in $46 \%$ and ALT in $30 \%$ of autistic children which was consistent with other investigators ${ }^{11}$, $12,17,18,24$.

It has been suggested that mitochondrial dysfunction causes TCA cycle abnormality leading to rise of serum lactate level ${ }^{10}$ Mitochondrial dysfunction also causes loss of some cellular integrity of muscle and liver and enzymes and serum aspartate aminotransferase and alanine aminotransferase level are rises ${ }^{1}$. 


\section{Conclusion}

From the result of this study, it may be concluded that mitochondrial dysfunction may occur in children with autistic spectrum disorder.

\section{Conflict of interest: None}

\section{Author affiliations}

1. *Mahmuda Karim, Assistant Professor, Department of Physiology, City Medical College and Hospital, Itahata, Gazipur, Dhaka. Email: bristy1980@ gmail.com. Tele: 01711070201.

2. Shelina Begum, Professor, Chairman, Department of Physiology, Bangabandhu Sheikh Mujib Medical University (BSMMU), Shahbag, Dhaka. Email: shelina1982@gmail.com

3. Shorifa Shahzadi, Assistant Professor, Department of Physiology, Bangabandhu Sheikh Mujib Medical University (BSMMU), Shahbag, Dhaka.

*For correspondence

\section{References}

1. Rossignol DA, Bradstreet JJ. Evidence of mitochondrial dysfunction in autism and implications for treatment. A J Biochem Biotechnol 2008; 4(2): 208217.

2. Filipek PA, Juranek J, Nguyen MT, Cummings C, Gargus JJ. Relative Carnitine Deficiency in Autism. Jl Autism Dev Disord 2004; 34(6) : 615-623.

3. Manzi B, Loizzo AL, Giana G, etal. Autism and metabolic diseases. J Child Neurology 2008; 23: 307314.

4. Lombard J. Autism: a mitochondrial disorder? Med Hypothesis 1998; 50(6): 497-500.

5. Rossignol DA, Frye RE. Mitochondrial dysfunction in autism spectrum disorders: a systemic review and meta-analysis. Mol. Psychiatry 2012; 17(3): 290-314.

6. Giulivi C, Zhang YF, Omanska-Klusek A, Ross-Inta C,Wong S, Hertz-Picciotto I, Tassone F. Mitochondrial dysfunction in autism. JAMA 2010; 304: 2389-2396.

7. Atamna H, Killilea DW, Killilea AN, Ames BN. Heme deficiency may be a factor in the mitochondrial and neuronal decay of aging. Proc Natl Acad Sci USA 2002; 99: 14807-14812.

8. Fowler BA, Woods JS. Ultrastructural and biochemical changes in renal mitochondria during chronic oral methyl mercury exposure: the relationship to renal function. Exp Mol Pathol 1977; 27: 403-412.

9. James SJ, Rose S, Melnyk S, Jernigan S, Blossom S, Pavliv $\mathrm{O}$ et al. Cellular and mitochondrial glutathione redox imbalance in lymphoblastoid cells derived from children with autism. FASEB J 2009; 23: 2374-2383.

10. Chinnery PF, Turnbull DM. Mitochondrial medicine. QJM 1997; 90: 657-667.

11. Weissman JR, Kelly RI, Bauman ML, Cohen BH, Murray KF, Mitchell RL, Kern RL, Natowicz MR. Mitochondrial disease in autism spectrum disorder patients: a cohort analysis. PLoS One 2008; 3(11):3815.

12. Poling JS, Frye RE, Shoffner J, Zimmerman AW. Developmental regression and dysfunction in children mitochondrial with autism. J Child Neurol 2006; 21: 170-172.

13. Marin-Garcia J, Ananthakrishnan R, Goldenthal MJ, Filiano JJ, Sarnat HB. Skeletal muscle mitochondrial defects in nonspecific neurologic disorders. Pediatr. Neurol 1999; 21(2): 538-42.

14. Schopler E, Reichler RJ, DeVellis RF, Daly K. Toward objective classification of childhood autism: Childhood Autism Rating Scale (CARS). J Autism Dev Disord 1980; 10 (1): 91-103.

15. Murray RK, Bender DA, Botham KM, Kennelly PJ, Rodwell VW, Weil AP. Harper's Illustrated Biochemistry 28th ed. India: Tata McGraw Hill Education Private Ltd; 2009.pp. 496- 497.

16. Diana Nicoll c. In: current medical diagnosis and treatment. 4th edition Stephen JM, Maxine AP, editors. Mc Graw Hill; 2007. Appendix: therapeutic drug monitoring and laboratory reference ranges; pp. 17671775.

17. Mostafa GA, El-Gamal HA, El-Wakkad ASE, ElShorbagy OE, Hamza MM. Polyunsaturated Fatty Acids, Carnitine and Lactate as a Biological markers of Brain Energy in Autistic Children. Int. J. Ch. Neuropsychiatry 2005; 2(2): 179-188.

18. Al-Musalem OA, El-Ansary A, Attas O, Al-Ayadhi L. Metabolic biomarkers related to energy metabolism in Saudi autistic children 2009; 42(10/11): 949-57.

19. El-Ansary A, Al-Daihan S, Al-Dabas A, Al-Ayadhi L. Activities of key glycolytic enzymes in the plasma of Saudi autistic patients. Open Access Journal of Clinical Trial 2010; 2: 49-57.

20. Frye RE. Biomarkers of Abnormal Energy Metabolism in Children with Autism Spectrum Disorder. N A J Med Sci 2012; 5(3): 141-147

21. Dhillon S, Jessica A, Hellings, Merlin G B. Genetics and Mitochondrial Abnormalities in Autism 
Spectrum Disorders: A Review 2011; 12(5): 322-332.

22. Oliveira G, Diogo L, Grazina M, Garcia P, Ataide A, Marques C, Miguel T, Borges L, Vicente AM, Oliveira CR. Mitochondrial dysfunction in autism spectrum disorders: a population based study. Dev Med Child Neurology 2005; 47:185-189.

23. Correia C, Coutinho AM, Diogo L, Grazina M, Marques C, Miguel T, et al. Brief report: high frequency of biochemical markers for mitochondrial dysfunction in autism: no association with the mitochondrial aspartate/glutamate carrier SLC25A12 gene. J Autism Dev Disord 2006; 36:1137-1140.

24. Bradstreet JJ, Smith S, Rossignol D A, Baral M. Biomarker-Guided Interventions of Clinically Relevant Conditions Associated With Autism Spectrum Disorders and Attention Deficit Hyperactivity Disorder. Alternative Medicine Review 2010; 15(1):15-32. 